\title{
ВПЛИВ I, SE, S ЦИТРАТУ НА ГЕМАТОЛОГІЧНИЙ ПРОФІЛЬ І ДИНАМІКУ МАСИ ТІЛА КУРЧАТ-БРОЙЛЕРІВ ЗА НАЯВНОСТІ ТА ВІДСУТНОСТІ КОКЦИДІОСТАТИКА В КОМБІКОРМІ
}

\author{
У. I. Тесарівська ${ }^{1}$, канд. вет. наук. \\ Р. С. Федорук ${ }^{2}$ д-р вет. наук, проф., членкор НААН, \\ О. I. Колешук ${ }^{2}$, канд. с.-г. наук, \\ С. Я. Мартиник ${ }^{1}$, науковий співробітник, \\ О. М. Максимович ${ }^{1}$, молодший науковий співробітник \\ ${ }^{1}$ Державний науково-дослідний контрольний інститут ветеринарних препаратів \\ та кормових добавок, \\ вул. Донецька, 11, м. Львів,790019, Україна \\ 2 Інститут біології тварин НААН, \\ вул. Василя Стуса, 38, м. Львів, 79034, Україна
}

Наведено результати впливу різних доз I, Se, S иитрату, синтезованого методом нанотехнологї на організм курчат-бройлерів на тлі наявності та відсутності кокцидіостатика «Кокичисан» в комбікормі. Випоювання з водою птиці 5, 10, 20, 30, 40 мкг I/л, за внесення до комбікорму кокцидіостатика впродовж перших 35 діб вирощування, зумовлює зменшення кількості еритрочитів і показника гематокриту за дії 40 мкг I/л. Після вилучення «Кокиисану» з фінішного комбікорму досліджувана сполука I, Se, S цฺитрату у застосованих дозах стимулює гемопоетичну функиію з підвищенням показника гематокриту, кількості еритроцитів за дї вищих (20; 30 i 40 мкг I/л) доз, а вмісту гемоглобіну в крові курчатбройлерів - тільки 20 і 40 мкг I/л. У крові птичі за дії 20 і 30 мкг I/л зменшувалась кількість лейкочитів і відносний рівень лімфоцитів. Вплив I, Se, S ичитрату у застосованих дозах на динаміку росту курчат-бройлерів більше виражений у завершальний період вирощування за умов вилучення «Кокиисану» з фінішного комбікорму.

Ключові слова: КУРЧАТА-БРОЙЛЕРИ, ГЕМАТОЛОГІЧНИЙ ПРОФІЛЬ, ДИНАМІКА МАСИ ТІЛА, БІОЛОГІЧНА ДІЯ, I, SE, S ЦИТРАТ.

На даний час однією з найважливіших проблем у промисловому птахівництві є питання, пов'язані 3 забезпеченням раціонального мінерального живлення та профілактика захворюваності сільськогосподарської птиці. Здорове поголів'я це запорука високої його продуктивності, що веде до підвищення рівня рентабельності галузі. Забезпечення сільськогосподарської птиці високоякісними кормами є одним із факторів поліпшення іiі збереженості та продуктивності, розробка нових ефективних композицій мікроелементів, які покращують збалансованість раціону птиці, підвищують іiі ріст, розвиток і природну резистентність організму є актуальною.

Важливою проблемою для медицини i ветеринарії залишається недостатність надходження I в організм людини і тварин у більшості регіонів України. Разом 3 тим йододефіцит сьогодні — це глобальна проблема всього людства яку не можна ігнорувати [14]. Біологічна роль йоду пов'язана з участю в біосинтезі гормонів щитоподібної залози. За фізіологічних умов потреба в йоді для дорослих людей становить близько 180 мкг на добу [5]. Дефіцит йоду призводить до зниження синтезу гормонів щитоподібної залози, які відіграють важливу роль у процесах порушення обміну речовин, росту і розвитку тканин, органів та 
цілого організму. Тіреоїдні гормони контролюють енергетичний обмін, беруть участь в білковому, жировому, вуглеводному та мінеральному обміні [6], корегують процесами розвитку та функціонування головного мозку, нервової системи $[7,8]$.

У перебігу метаболічних процесів важливу функцію також відіграє Se [9], який входить до низки ферментів, що разом 3 каталазою та супероксиддисмутазою формують ферментативну ланку системи антиоксидантного захисту організму [10]. 3 дефіцитом Селену в організмі пов'язують такі захворювання, як: серцево-судинні та онкологічні, дисфункцію щитоподібної залози, зниження імунітету, порушення обміну речовин та інші. Здатність щитоподібної залози нагромаджувати не лише I, але й Se вказує на важливу їх роль для фізіологічного функціонування цього органу та життєдіяльності організму $[11,12]$. Відомо, що в тканинах щитоподібної залози міститься більше Se, ніж у мозку та в інших органах [13].

Не менш важлива роль в організмі належить $\mathrm{S}$, яка бере участь в окисно-відновних реакціях, тканинному диханні, виробництві енергії та передачі генетичної інформації. Доведено, що $\mathrm{S}$ захищає клітини, тканини і весь організм від токсичного впливу різних мікроорганізмів і речовин, утворює ендогенну $\mathrm{H}_{2} \mathrm{SO}_{4}$, яка бере участь у дезактивації фенолів, індолу та лікарських засобів [14]. Дефіцит цього мікроелемента пригнічує синтез сульфурвмісних амінокислот, що супроводжується зниженням продуктивності птиці зі зменшенням обміну сполук азоту $[14,15]$.

Один із способів вирішення проблеми зі забезпечення організму необхідними мікроелементами є збагачення ними раціонів для годівлі тварин і птиці. Це дає змогу отримати продукцію з підвищеною концентрацією в ній певних мікроелементів. Як кормові добавки для тварин на території $\mathrm{CC}$ затверджені йодати $(\mathrm{Ca}(\mathrm{IO} 3) 2 \cdot 6 \mathrm{H} 2 \mathrm{O} ; \mathrm{Ca}(\mathrm{IO} 3) 2$ і йодиди (NaI, $\mathrm{KI})[16]$. Також поширеними добавками у тваринництві $\epsilon$ органічна сполука йоду етилендіаміндигідройодид (EDDI) [17], йодований казеїн (KI + казеїн мелений), пентакальційортоперйодат [18] та інші. Потребу високопродуктивних тварин та птиці у селені можна задовольнити введенням у раціон преміксів, до складу яких входить неорганічна форма селену - селеніт натрію та створена його органічна форма - селенометіонін [19, 20]. Джерелом Сульфуру для організму тварин та птиці є комбікорм, до якого додають сульфат натрію [21, 22].

Широкий спектр біологічної активності мікроелементів дає підстави провести вивчення впливу на організм тварин та птиці композиції I, Se, S цитрату, отриманої методом нанотехнології.

Результати попередніх досліджень I, Se, S цитрату на щурах вказують на виражену ефективну їх дію, без проявів токсичного впливу на організм у низьких концентраціях [23]. Тому метою наших досліджень було вивчення впливу I, Se, S цитрату у різних дозах на організм курчат-бройлерів, за випоювання його з водою впродовж повного технологічного циклу вирощування, за умов застосування кокцидіостатика і без нього.

Матеріали і методи. Дослідження проведені на курчатах-бройлерах обох статей кросу ROSS-308. У добовому віці з птиці сформували контрольну (K) і 5 дослідних (Д I-Д V) груп, по 10 особин у кожній. Курчат утримували у віварії Державного науково-дослідного контрольного інституту ветпрепаратів та кормових добавок на підлозі, як підстилку використовували стружку з деревини. Загальна площа виробничого приміщення $32,5 \mathrm{~m}^{2} 3$ об'ємом 81 м 3 була розділена на 6 секцій. Освітлення становило 18-24 год/добу і залежало від віку птиці. Використовувались як природні, так і штучні джерела освітлення. Повітрообмін в приміщеннях забезпечувався примусовою вентиляцією і регулювався залежно від віку та маси птиці. Відповідно до технологічної карти, температурний режим становив $33-31{ }^{\circ} \mathrm{C}$ у $1-7$ доби та знижувався у наступні періоди за схемою: 8-14 доби - 31-29 ${ }^{\circ} \mathrm{C} ; 15-21-29-27{ }^{\circ} \mathrm{C} ; 22-28-$ 27-25 ${ }^{\circ} \mathrm{C} ; 29-35-25-22{ }^{\circ} \mathrm{C} ; 36-42-22-19{ }^{\circ} \mathrm{C} ; 43-48$ доби - $19{ }^{\circ} \mathrm{C}$. Підтримування вказаної температури забезпечувалося централізованим опаленням 3 використанням локального обігріву курчат за допомогою електроламп "Infra-Rush". Вся птиця одержувала стандартний 
комбікорм, збалансований за поживними $\mathrm{i}$ біологічно активними речовинами, який рекомендований для даного віку згідно з технологією утримання. У повнораціонний комбікорм для курчат-бройлерів «Стартер» $\mathrm{i}$ «Гровер» на етапах його виготовлення додавали 0,5 кг/т кокцидіостатика «Кокцисан 12 \%» (фірма KRKA, Словенія). За 12 діб до забою згодовували комбікорм «Фініш» у який кокцидіостатик не вносили. Для годівлі птиці використовувалися групові годівниці, розмір і висота від підлоги яких залежала від віку. Напування забезпечувалось поїлками об'ємом 1 і 6 л відповідно до вікових періодів птиці з додаванням до питної води різної кількості розчину I, Se, S цитрату, виготовленого методом нанотехнології. Курчатам Д I групи випоювали найнижчу дозу I, Se, S цитрату у співвідношенні I - 3: Se - 1: S - 5 частин з розрахунку 5 мкг I/л. питної води, а для птиці інших дослідних груп ії̈ збільшували у 2 (Д II), 4 (Д III), 6 (Д IV) і 8 (Д V) разів, порівняно з Д I групою. Впродовж 48-добового технологічного періоду вирощування щоденно контролювали клінічний стан птиці і через кожні 7 діб вимірювали масу тіла.

Кров для досліджень отримували (3 subcrine vein) на 35 добу росту курчат - у період споживання кокцидіостатика, а також на 48 добу (при декапітації) - на 13 добу після припинення використання кокцидіостатика. Всі маніпуляції з птицею та ії забій проводили 3 дотриманням біоетичних вимог [24]. Матеріалом для досліджень слугувала кров, яку відбирали після забою. У гепаринізованій крові визначали вміст гемоглобіну гемоглобінціанідним методом, величину гематокриту - методом мікроцентрифугування, кількість еритроцитів та лейкоцитів підраховували у камері з сіткою Горяєва, лейкограму шляхом мікроскопії мазків крові, зафарбованих барвником Романовського-Гімзи [25]. Одержані результати опрацьовували методом статистичного аналізу 3 використанням комп'ютерної програми і визначенням середніх величин $(\mathrm{M})$, їх відхилень $( \pm \mathrm{m})$ та ступеня вірогідності $(\mathrm{p}<0,05)$ за коефіцієнтом Стьюдента.

Результати й обговорення. Випоювання курчатам-бройлерам з водою I, Se, S цитрату в різних дозах на тлі введення до комбікорму кокцидіостатика «Кокцисан» вірогідно не впливало на кількість еритроцитів, лейкоцитів та їх форм, умісту гемоглобіну у крові на 35 добу росту й розвитку, порівняно із показниками птиці контрольної (К) групи, окрім гематокриту, який у курчат Д V групи був на 23 \% менший, ніж у контролі (табл. 1).

Морфологічні показники крові курчат-бройлерів на 35 добу росту (M \pm m), n=5

\begin{tabular}{|c|c|c|c|c|c|c|c|}
\hline \multirow{3}{*}{ Показники } & \multirow{3}{*}{$\begin{array}{c}\text { Одиниці } \\
\text { вимірю- } \\
\text { вання }\end{array}$} & \multicolumn{6}{|c|}{ Групи тварин } \\
\hline & & \multirow{2}{*}{$\frac{\text { контрольна }}{\mathrm{K}}$} & \multicolumn{5}{|c|}{ дослідні - доза I, Se, S за концентрацією I у воді мкг /л } \\
\hline & & & Д I - 5. & Д II - 10 & Д III - 20 & Д IV - 30 & Д V -40 \\
\hline Еритроцити & $10^{12} /$ л & $2,83 \pm 0,27$ & $2,53 \pm 0,17$ & $2,50 \pm 0,25$ & $2,70 \pm 0,42$ & $2,60 \pm 0,15$ & $2,50 \pm 0,13$ \\
\hline Гемоглобін & г/л & $106,30 \pm 7,73$ & $93,90 \pm 5,32$ & $100,91 \pm 5,76$ & $107,52 \pm 11,79$ & $104,82 \pm 2,56$ & $99,25 \pm 0,45$ \\
\hline Гематокрит & л/л & $0,35 \pm 0,01$ & $0,28 \pm 0,04$ & $0,34 \pm 0,04$ & $0,31 \pm 0,05$ & $0,31 \pm 0,03$ & $0,27 \pm 0,02 * *$ \\
\hline Лейкоцити & $10^{9} / л$ & $32,50 \pm 4,70$ & $38,70 \pm 1,80$ & $34,32 \pm 3,70$ & $32,01 \pm 4,60$ & $28,74 \pm 1,30$ & $27,31 \pm 1,50$ \\
\hline Лімфоцити & $\%$ & $54,70 \pm 1,80$ & $58,00 \pm 1,20$ & $56,71 \pm 1,80$ & $56,02 \pm 2,00$ & $54,00 \pm 3,00$ & $57,32 \pm 0,70$ \\
\hline Моноцити & $\%$ & $6,00 \pm 0,01$ & $5,00 \pm 0,60$ & $5,30 \pm 0,70$ & $6,00 \pm 0,01$ & $5,30 \pm 0,70$ & $5,30 \pm 0,70$ \\
\hline Еозинофіли & $\%$ & $6,00 \pm 1,20$ & $7,00 \pm 0,60$ & $6,00 \pm 0,01$ & $6,70 \pm 0,70$ & $4,00 \pm 1,20$ & $7,30 \pm 0,70$ \\
\hline $\begin{array}{l}\text { Псевдо- } \\
\text { еозинофіли }\end{array}$ & $\%$ & $33,31 \pm 1,80$ & $30,00 \pm 0,01$ & $32,01 \pm 1,20$ & $31,33 \pm 1,80$ & $36,73 \pm 1,70$ & $30,04 \pm 1,20$ \\
\hline
\end{tabular}

Примітка: у цій та наступних таблицях * $-\mathrm{P}<0,05 ; * *-\mathrm{P}<0,01 ; * * *-\mathrm{P}<0,001$.

Також відзначено тенденцію до меншої кількості еритроцитів, гематокриту і вмісту гемоглобіну у крові курчат Д I, Д II і Д IV, Д V груп порівняно з їх показниками у птиці К групи. Характерно, що більше вираженим це зниження $є$ для курчат-бройлерів Д V групи за дії найвищої (40 мкг I/л) дози I, Se, S цитрату. Встановлені відмінності цих показників у крові дослідних і контрольної груп вказують на незначний інгібуючий вплив тривалого випоювання 
(35 діб) високої дози I, Se, S цитрату курчатам-бройлерам, на тлі згодовування впродовж цього періоду «Кокцисану».

Кількість лейкоцитів та лейкограма крові курчат дослідних груп вірогідно не відрізнялись від їх показників у птиці контрольної групи. Встановлено найнижчий рівень лейкоцитів у крові курчат Д IV і Д V груп за дії 30 і 40 мкг I/л, відповідно. Однак, різниці їх величин, порівняно з цими показниками у птиці контрольної групи, суттєво не відрізнялись від середньої похибки ( \pm m) кількості лейкоцитів у цих групах.

Аналіз змін морфологічних показників крові у технологічний період забою курчат на 48 добу росту і розвитку та виключення 3 фінішного комбікорму «Кокцисану» вказує на вірогідні їх різниці між дослідними та контрольною групами (табл. 2).

Таблиия 2

Морфологічні показники крові курчат-бройлерів на 48 добу росту (M \pm m), n=5

\begin{tabular}{|c|c|c|c|c|c|c|c|}
\hline \multirow{3}{*}{ Показники } & \multirow{3}{*}{$\begin{array}{c}\text { Одиниці } \\
\text { вимірю- } \\
\text { вання }\end{array}$} & \multicolumn{6}{|c|}{ Групи тварин } \\
\hline & & \multirow{2}{*}{$\frac{\text { контрольна }}{\mathrm{K}}$} & \multicolumn{5}{|c|}{ дослідні - доза I, Se, S за концентрацією I у воді мкг /л } \\
\hline & & & Д I - 5. & Д II - 10 & Д III - 20 & Д IV - 30 & Д V -40 \\
\hline Еритроцити & $10^{12 / л}$ & $2,81 \pm 0,30$ & $2,9 \pm 0,30$ & $2,72 \pm 0,20$ & $4,19 \pm 0,20 * *$ & $4,10 \pm 0,20 * *$ & $4,19 \pm 0,30 * *$ \\
\hline Гемоглобін & г/л & $97,12 \pm 2,80$ & $106,41 \pm 6,20$ & $93,61 \pm 4,30$ & $108,61 \pm 4,50 *$ & $94,88 \pm 2,20$ & $112,02 \pm 1,30 * *$ \\
\hline Гематокрит & Л/л & $0,30 \pm 0,01$ & $0,33 \pm 0,01 *$ & $0,31 \pm 0,01$ & $0,32 \pm 0,01$ & $0,31 \pm 0,01$ & $0,34 \pm 0,01 * *$ \\
\hline Лейкоцити & $10^{9} /$ л & $36,74 \pm 2,30$ & $33,22 \pm 3,70$ & $39,43 \pm 3,00$ & $28,0 \pm 2,10^{*}$ & $27,48 \pm 2,00 *$ & $34,38 \pm 3,90$ \\
\hline Лімфоцити & $\%$ & $54,71 \pm 0,70$ & $60,04 \pm 3,50$ & $60,72 \pm 0,70 * *$ & $51,29 \pm 1,80$ & $50,02 \pm 1,20 *$ & $54,03 \pm 2,00$ \\
\hline Моноцити & $\%$ & $5,30 \pm 0,70$ & $4,00 \pm 0,20$ & $4,00 \pm 0,20$ & $6,00 \pm 0,20$ & $5,30 \pm 0,70$ & $5,27 \pm 0,70$ \\
\hline Еозинофіли & $\%$ & $6,70 \pm 0,70$ & $6,70 \pm 1,30$ & $4,70 \pm 0,70$ & $7,30 \pm 0,70$ & $6,70 \pm 0,70$ & $7,30 \pm 0,70$ \\
\hline $\begin{array}{l}\text { Псевдо- } \\
\text { еозинофіли }\end{array}$ & $\%$ & $33,32 \pm 0,70$ & $29,33 \pm 2,40$ & $30,74 \pm 0,70$ & $35,27 \pm 1,30$ & $38,03 \pm 1,20 *$ & $33,31 \pm 1,80$ \\
\hline
\end{tabular}

Зокрема, випоювання вищих доз I, Se, S цитрату курчатам Д III - Д V груп зумовлювало вірогідне зростання в крові кількості еритроцитів, відповідно, на 54, 50, 54 \%, а вмісту гемоглобіну - на 17 та 22 \%, відповідно, в Д III та Д V групах, порівняно з їх величинами у курчат контрольної групи.

Це може вказувати на стимулюючий вплив вилучення 3 комбікорму кокцидіостатика «Кокцисан» у фінішний період вирощування курчат-бройлерів за дії більших доз I (Д III і Д V групи, 20 і 40 мкг I/л), на формування еритроцитів і синтез гемоглобіну в організмі.

Випоювання I, Se, S цитрату курчатам Д I і Д V груп у дозах 5 i 40 мкг I/л впродовж вирощування вірогідно підвищує гематокрит, відповідно, на 10,0 та 13,3%, порівняно 3 його рівнем у курчат контрольної групи.

Відзначено нижчий рівень лейкоцитів за дії 20 і 30 мкг I/л (Д III - на 23,7 \% і Д IV - на $25,1 \%, \mathrm{p}<0,05)$, а не вірогідно - в Д I і Д V групах. Аналіз лейкограми крові курчат вказує на вищий на $11 \%(\mathrm{p}<0,01)$ відносний рівень лімфоцитів у крові курчат Д II групи за дії 10 мкг I/л, але зниження його за дії 20 мкг I/л на 6,2%, а 30 мкг I/л - на 8,6 \% (p < 0,05). Характерно, що зменшення відносного рівня лімфоцитів у крові курчат Д IV групи відзначено на тлі підвищення на $14,1 \%(\mathrm{p}<0,05)$ рівня псевдоеозинофілів. Це може вказувати на активуючий вплив цієї дози I, Se, S цитрату на їх надходження у периферичне русло. Аналогічна тенденція невірогідних змін щодо цього показника відзначена у крові курчат Д IV групи на 35 добу вирощування, у період дії «Кокцисану».

Дослідження динаміки маси тіла курчат-бройлерів вказують, що введення I, Se, S цитрату сприяло підвищенню інтенсивності росту всіх дослідних груп птиці у перші 7 днів, окрім Д IV, зокрема у курчат Д I - на 9,0 \% (p < 0,05), Д II - на 7,8 \% (p < 0,05), Д III - на 10,2 \% $(\mathrm{p}<0,05)$, Д $\mathrm{V}-$ на $8,6 \%(\mathrm{p}<0,05)$ (рис.). 


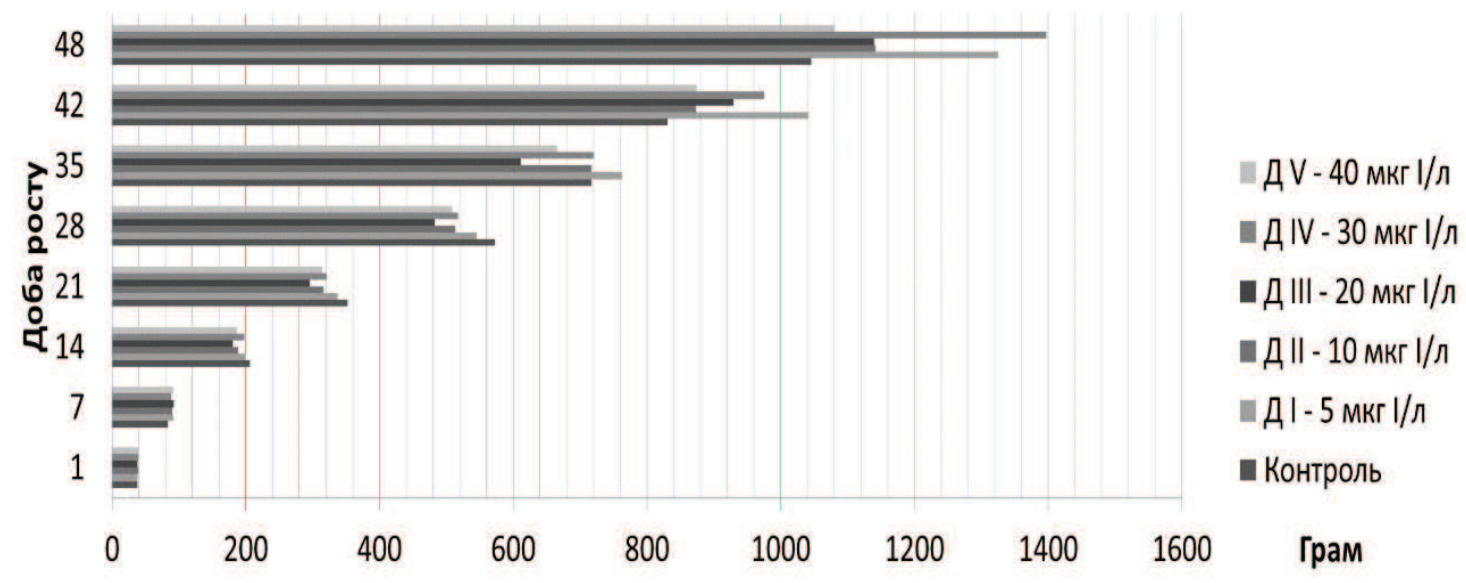

Puc. Динаміка змін маси тіла курчат-бройлерів у період застосування різних доз I, Se, S цитрату, n=10

На 21-28 доби вирощування відзначено зниження показників маси тіла курчат всіх дослідних груп, зокрема у курчат Д I - на 4,3 / 4,7 \%, Д II - на 10,3 / 10,4 \%, Д III - на 15,9 (p < 0,05) / 15,7 \% (p < 0,05), Д IV - на 8,6 / 9,7 \%, Д V - на 10,7 (p < 0,05) / 11,1 \%, стосовно контролю, що може бути пов'язано з пригніченням біологічної та продуктивної дії I, Se, S цитрату «Кокцисаном». Найнижчу масу тіла курчат на 14-35 добу росту встановлено в Д III групі за дії 20 мкг I/л і вказує на вірогідні їх різниці між дослідними та контрольною групами. У той час як найменша доза (5 мкг I/л) стимулювала ріст курчат Д I групи, відносна маса тіла яких була вищою на 35 добу росту на 6,5 \%, порівняно з цим показником у птиці контрольної групи. Маса тіла курчат Д II і Д IV груп на 35 добу утримувалась на рівні контрольної групи, а Д V була меншою на 7,1%, відповідно. Вилучення «Кокцисану» 3 комбікорму курчат Д I - Д V i K груп сприяло підвищенню інтенсивності їх росту впродовж наступних періодів (42 i 48 доби) в дослідних групах, порівняно 3 контрольною. Це вказує на прояв позитивного метаболічного впливу I, Se, S цитрату в організмі курчат-бройлерів за відсутності можливого його інгібування «Кокцисаном». Більше виражену продуктивну дію на 42 і 48 доби встановлено у курчат Д I (на 25,5 (p < 0,05) / 26,7 \% (p < 0,05) і Д IV (на 17,5 / 33,6 \% (p < 0,05) груп, що може свідчити про відсутність прямої дозової залежності впливу I, Se, S цитрату у застосованому співвідношенні цих мікроелементів на приріст маси тіла курчат-бройлерів у фінішний період вирощування після вилучення кокцидіостатика з раціону.

\section{В И С Н О В К И}

1. Випоювання курчатам-бройлерам впродовж перших 35 діб вирощування 5, 10, 20, 30, 40 мкг I/л, за рахунок I, Se, S цитрату, синтезованого методом нанотехнології, на тлі внесення до комбікорму кокцидіостатика «Кокцисан», зумовлює зменшення кількості еритроцитів $\mathrm{i}$ показника гематокриту за дії 40 мкг I/л. Це може вказувати на інгібуючий вплив цієї дози I, Se, $\mathrm{S}$ цитрату на надходження еритроцитів у периферичну кров.

2. Продовження дії I, Se, S цитрату на організм птиці у застосованих дозах після вилучення «Кокцисану» 3 фінішного комбікорму стимулює гемопоетичну функцію 3 підвищенням показника гематокриту, кількості еритроцитів в крові курчат-бройлерів за дії вищих доз (20, 30 і 40 мкг I/л), а вмісту гемоглобіну - тільки 20 і 40 мкг I/л. У крові курчатбройлерів за дії 20 і 30 мкг I/л зменшувалася кількість лейкоцитів, відносний рівень лімфоцитів та псевдоеозинофілів.

3. Вплив I, Se, S цитрату у застосованих дозах на динаміку росту курчат-бройлерів більше виражений у завершальний період вирощування (42-48 доби), за умов вилучення «Кокцисану» з фінішного комбікорму. Вищі показники маси тіла птиці відзначено в Д I та Д IV 
групах за дії 5 і 30 мкг I/л.

Перспективи досліджень. Доцільним є вивчення впливу різних концентрацій I, Se, S цитрату на гормон-синтезуючу функцію щитоподібної залози, що буде виконано у наступних дослідженнях.

\title{
THE INFLUENCE OF CITRATE I, SE, S ON THE HEMATOLOGICAL PROFILE AND BODY WEIGHT DYNAMICS OF BROILER CHICKENS IN THE PRESENCE AND ABSENCE OF COCCIDIOSTATICS IN THE MIXED FEED
}

\author{
U. I. Tesarivskaya ${ }^{1}$, R. S. Fedoruk ${ }^{2}$, O. I. Koleschuk ${ }^{2}$, S. Ya. Martynyk ${ }^{1}$, O. M. Maksymovych ${ }^{1}$
}

${ }^{1}$ State Scientific Research Control Institute of Veterinary Medicinal Products and Feed Additives, 11. Donetska str., Lviv, 79019, Ukraine

${ }^{2}$ Institute of Animal Biology of NAAS

38. V. Stusa str., Lviv, 79034, Ukraine

\section{S U M M A R Y}

The results of the influence of different doses of I, Se, S citrate, synthesized by the method of nanotechnology on the body of chicken broilers with the presence and absence of the coccidiostatic «Coccisan» in the feed are given. The drinking with water of 5, 10, 20, 30, $40 \mu \mathrm{g} \mathrm{I} / \mathrm{L}$ when introduced into the mixed fodder coccidiostatic probably did not affect the number of red blood cells, leukocytes and their forms, the content of hemoglobin in the blood of 35 days of growth and development compared with the control of poultry in the control group, except for the hematocrit, which was chicken in the action of $40 \mu \mathrm{g} \mathrm{I} / \mathrm{L}$ was lower than in the control. The number of leukocytes and leukogram in the blood of chickens in experimental groups was not significantly different from those in the poultry of the control group. Analysis of changes in morphological parameters of blood during the technological period of slaughter of chicks on the 48th day of growth and development and exclusion from the finishing mixed fodder «Coccisan» indicates the probable increase in the number of red blood cells in chickens in the blood of 20; 30 and $40 \mu \mathrm{g} \mathrm{I} \mathrm{/} \mathrm{L,} \mathrm{hemoglobin} \mathrm{content} \mathrm{at} \mathrm{the} \mathrm{action}$ of 20 and $40 \mu \mathrm{g} \mathrm{I} / \mathrm{L}$, hematocrit values at the action of 5 and $40 \mu \mathrm{g} \mathrm{I} / \mathrm{L}$ compared to the control group chickens. The lower level of leukocytes is noted for the actions of 20 and $30 \mu \mathrm{g} \mathrm{I} / \mathrm{L}$. An analysis of blood chicken leukograms indicates a higher relative lymphocyte level in the blood of chickens at $10 \mu \mathrm{g} \mathrm{I} / \mathrm{L}$, but decreasing it by action of $20 \mu \mathrm{g} \mathrm{I} / \mathrm{L}$ and $30 \mu \mathrm{g} \mathrm{I} / \mathrm{L}$. Characteristically, a decrease in the relative level of lymphocytes in the blood of chickens at the action of $40 \mu \mathrm{g} \mathrm{I} / \mathrm{L}$ was noted with an increase in the level of pseudoiesinophils.

Investigation of the body weight of chicken broilers indicates that the introduction of I, Se, S citrate contributed to the increase in the intensity of growth of all experimental poultry species in the first 7 days, except for the actions of $30 \mu \mathrm{g} \mathrm{I} / \mathrm{L}$. At $21-28$ days of cultivation, there is no probable decrease in the body weight index of chickens in all experimental groups. The lowest body weight of chickens for 14 - 35 days of growth is set at the action of $20 \mu \mathrm{g} \mathrm{I} / \mathrm{L}$. Excretion of «Coccisan» from mixed fodder contributed to an increase in the intensity of their growth of chickens during subsequent periods (42 and 48 days) in experimental groups compared with the control group. A more pronounced productive effect at 42 and 48 days is found in chickens at the action of $10 \mu \mathrm{g} \mathrm{I} / \mathrm{L}$ and $40 \mu \mathrm{g} \mathrm{I} / \mathrm{L}$.

Keywords: CHICKEN BROILERS, HEMATOLOGICAL PROFILE, DYNAMICS OF BODY WEIGHT, BIOLOGICAL ACTION, CITRATE I, SE, S. 


\title{
ВЛИЯНИЕ I, SE, S ЦИТРАТА НА ГЕМАТОЛОГИЧЕСКИЙ ПРОФИЛЬ И ДИНАМИКУ МАССЫ ТЕЛА ЦЫПЛЯТ-БРОЙЛЕРОВ ПРИ НАЛИЧИИ И ОТСУТСТВИИ КОКЦИДИОСТАТИКА В КОМБИКОРМЕ
}

\author{
У. И. Тесаривская ${ }^{1}$, Р. С. Федорук ${ }^{2}$, О. И. Колещук², С. Я. Мартыныкк', О. Н. Максимович ${ }^{1}$ \\ ${ }^{1}$ Государственный научно-исследовательский контрольный институт ветеринарных \\ препаратов и кормовых добавок, \\ ул. Донецкая, 11, м. Львов,790019, Украина \\ ${ }^{2}$ Институт биологии животных НААН \\ ул. Василия Стуса, 38, г. Львов, 79034, Украина
}

\section{А Н Н О Т А ЦИ Я}

Наведены результаты влияния различных доз I, Se, S цитрата, синтезированного методом нанотехнологии на организм цыплят-бройлеров на фоне наличия и отсутствия кокцидиостатика «Кокцисан» в комбикорме. Выпаивание с водой птице 5, 10, 20, 30, 40 мкг I/л, при внесении в комбикорм кокцидиостатика в течение первых 35 суток выращивания, приводит к уменьшению количества эритроцитов и показателя гематокрита при действии 40 мкг I/л. После изъятия «Кокцисана» из финишного комбикорма исследованное соединение I, $\mathrm{Se}, \mathrm{S}$ цитрата в применяемых дозах стимулирует гемопоэтическую функцию с повышением показателя гематокрита, количества эритроцитов при действии высших доз (20, 30 и 40 мкг I/л), а содержание гемоглобина в крови цыплят-бройлеров - только 20 и 40 мкг I/л. В крови птицы при действии 20 и 30 мкг I/л уменьшалось количество лейкоцитов и относительный уровень лимфоцитов. Влияние I, Se, S цитрата в применяемых дозах на динамику роста цыплят-бройлеров более выражено в завершающий период выращивания в условиях изъятия «Кокцисана» из финишного комбикорма.

КлючевЫе слова: ЦЫПЛЯТА-БРОЙЛЕРЫ, ГЕМАТОЛОГИЧЕСКИЙ ПРОФИЛЬ, ДИНАМИКА МАССЫ ТЕЛА, БИОЛОГИЧЕСКОЕ ДЕЙСТВИЕ, ЦИТРАТ I, SE, S.

\section{Л I T E P A T У P A}

1. WHO, UNICEF, and ICCIDD. Assessment of the Iodine Deficiency Disorders and monitoring their elimination. - Geneva: WHO, WHO/Euro/NUT, 2001. - P. 1-107.

2. WHO, UNICEF, and ICCIDD. Assessment of the Iodine Deficiency Disorders and monitoring their elimination. Third edition. - Geneva: WHO, WHO/Euro/NUT, 2007. - P. 1-98.

3. Zimmermann M. B. Iodine Deficiency/ M. B. Zimmermann // Endocrine Reviews. 2009. — Vol. 30 (4). — P. 376-408.

4. Zimmermann M. B. Iodine-deficiency disorders / M. B. Zimmermann, P. L. Jooste, C. S. Pandav // Lancet. - 2008. - Vol. 372 (9645). - P. 1251-1262.

5. Передерій В. Г. Основи внутрішньої медицини / В. Г. Передерій, С. М. Ткач Вінниця : Нова Книга, 2009. - Т. 1, - 639 с.

6. Pedraza P. E. Mechanisms of adaptation to iodine deficiency in rats: Thyroid status is tissue specific. Its relevance for man / P. E. Pedraza, M. J. Obregon, H. F. Escobar-Morreale, del F. E. Rey, de G. M. Escobar, M. J. Obregon, H. F. Escobar-Morreale, del F. E. Rey, de G. M. Escobar // Endocrinology. - 2006, - P. 2098-2108.

7. Bernal J. Thyroid hormones and brain development / J. Bernal // Vitam. Horm. - 2005, - P. 95-122.

8. Manzano J. Influence of thyroid hormones on maturation of rat cerebellar astrocytes / J. 
Manzano, J. Bernal, B. Morte // Int. J. Dev. Neurosci. — 2007, - P. 171-179.

9. Köhrl J. Selenium in biology: facts and medical perspectives / J. Köhrl, R. BrigeliusFlohe, A. Böck, et al. // Biol. Chem. - 2000. - Vol. 381, № 9-10. - P. 849-864.

10. Барабой B. A. Селен: биологическая роль и антиоксидантная активность / В. А. Барабой, Е. Н. Шестакова // Укр. біохім. журн. - 2004. - Т. 76, № 1.- С. 23-32.

11. Beckett, G. J. Selenium and endocrine systems. / G. J. Beckett, J. R. Arthur // J. Endocrinol, - 2005. -, Vol.184. - I. 3. - P. 455 - 465.

12. Поєднаний дефіцит йоду i селену та його вплив на перебіг вагітності / А. Ю. Лиманська, Ю. В. Давидова, О. М. Мокрик, Л. М. Булик / Вісник проблем біології і медицини - 2016 - Вип. 2, Том 3 (130).- С. 52- 56.

13. Schomburg L. On the importance of selenium and iodine metabolism for thyroid hormone biosynthesis / L. Schomburg, J. Köhrle // Mol. Nutr. Food Res. - 2008. - Vol. 52. - I. 11. - P. 1235 1246.

14. Oberlis $D$. The biological role of macro- and micronutrients in humans and animals / D. Oberlis, B. Garland, A. Skalny // SPb. The science. - 2008. - 542 p.

15. Migues $P$. $V$. Dehydroepiandrosterone and its sulphate enhance memory retention in dayold chicks / P. V. Migues, A. N. B. Johnsto, S. P. R Rose // Neurosci. - 2002 -Vol 109, I.2. - P. $243-$ 251.

16. Commission Regulation (EC) No 1459/2005 of 8 Sept. 2005 amending the conditions for authorisation of a number of feed additives belonging to the group of trace elements. Official Journal of the European Union L233. - 2005 - P. 8-10

17. Herzig I. Utilisation of iodine from different sources in pigs / I. Herzig, B. Pisaikova, J. Kursa, P. Suchy // Arch Tierernahr. - 2000. - Vol. 53, N 2. - P. 179-189.

18. Антоняк Г. Л. Біохімічна та геохімічна роль йоду: монографія / Г. Л. Антоняк, В. В. Влізло // ЛНУ ім. Івана Франка, 2013. - 392 с.

19. Artelt H. M. Selenium in Swine Nutrition / H. M. Artelt // RETORTE Ulrich Scharrer GmbH, Germany. -Vol. 10. - 2001. - P. 112-119.

20. Surai P. F. Is Organic selenium letter fjr animals than inorganic sources / P. F. Surai, J. E. Dvorska // Feed Mix. - 2001. - Vol. 9. - P. 8-10.

21. Антиоксидантний статус організму курей у критичні періоди росту і розвитку за додаткового введення мінеральної добавки до раціонів / Я. М. Сірко, Б. Я. Кирилів, В. О. Кисців та ін. // Наук.-техн. бюл. Ін-ту біології тварин та ДНДКІ ветпрепаратів та корм. добавок. - 2014. - Вип. 15, N 1. - С. 77-83.

22. Лесик Я. В. Резистентність організму кролів та динаміка маси тіла кроленят за умов випоювання сполук хрому(III) і сульфату натрію / Я. В. Лесик, Р. С. Федорук, О. П. Долайчук // Біологія тварин. - 2014. - 16, № 3. - С. 76-84.

23. Тесарівська У. I. Метаболічна і токсична дія різних доз «наноцитратів» I, Se, S в організмі лабораторних щурів / У. І. Тесарівська, Р. С. Федорук, В. Г. Каплуненко, та ін. // Вісник Сумського національного аграрного університету. - 2018 . - № 1 (42). - С. 220-224.

24. European convention for the protection of vertebrate animals used for experim. and other scientific purposes. Coun. of Europe, Strasbourg. 1986. pp. 53.

25. Влізло B. B. Лабораторні методи досліджень у біології, тваринництві та ветеринарній медицині : довідник / В. В. Влізло, Р. С. Федорук, І. Б. Ратич, та ін.; за ред. В. В. Влізла. - Львів : СПОЛОМ, 2012. — 764 с.

\section{References}

1. WHO, UNICEF, and ICCIDD. Assessment of the Iodine Deficiency Disorders and monitoring their elimination. - Geneva: WHO, WHO/Euro/NUT, 2001. - P. 1-107.

2. WHO, UNICEF, and ICCIDD. Assessment of the Iodine Deficiency Disorders and 
monitoring their elimination. Third edition. - Geneva: WHO, WHO/Euro/NUT, 2007. - P. 1-98.

3. Zimmermann M. B. Iodine Deficiency / M. B. Zimmermann // Endocrine Reviews. 2009. - Vol. 30 (4). - P. 376-408.

4. Zimmermann M. B. Iodine-deficiency disorders / M. B. Zimmermann, P. L. Jooste, C. S. Pandav // Lancet. - 2008. — Vol. 372 (9645). — P. 1251-1262.

5. Perederiy V. H. Osnovy vnutrishn'oyi medytsyny / V. H. Perederiy, S. M. Tkach Vinnytsya: Nova Knyha, 2009. - T. 1, 639 s. (in Ukrainian)

6. Pedraza P. E. Mechanisms of adaptation to iodine deficiency in rats: Thyroid status is tissue specific. Its relevance for man / P. E. Pedraza, M. J. Obregon, H. F. Escobar-Morreale, del F. E. Rey, de G. M. Escobar, M. J. Obregon, H. F. Escobar-Morreale, del F. E. Rey, de G. M. Escobar // Endocrinology. - 2006, - P. 2098-2108

7. Bernal J. Thyroid hormones and brain development / J. Bernal // Vitam. Horm. - 2005, - P. 95-122.

8. Manzano $J$. Influence of thyroid hormones on maturation of rat cerebellar astrocytes / J. Manzano, J. Bernal, B. Morte // Int. J. Dev. Neurosci. — 2007, — P.171-179.

9. Köhrl J. Selenium in biology: facts and medical perspectives / J. Köhrl, R. BrigeliusFlohe, A. Böck, et al. // Biol. Chem. - 2000. - Vol. 381, № 9-10. - P. 849-864.

10. Baraboy V. A. Selen: biolohichna rol' i antyoksydantna aktyvnist' / V. A. Baraboy, E. N. Shestakova // Ukr. biokhim. zhurn. - 2004. - T. 76, № 1.- S. 23-32.11.

11. Beckett, G. J. Selenium and endocrine systems. / G. J. Beckett, J. R. Arthur // J. Endocrinol, - 2005. -, Vol.184. - I.3. - P.455 - 465 .

12. Poyednanyy defitsyt yodu i sela ta yoho vplyv na perebih vahitnosti / A. YU. Lymans'ka, YU. V. Davydova, O. M. Mokryk, L. M. Bulyk // Visnyk problem biolohiyi i medytsyny - 2016 Vyp. 2, Tom 3 (130). 52- 56. (in Ukrainian)

13. Schomburg L. On the importance of selenium and iodine metabolism for thyroid hormone biosynthesis / L. Schomburg, J. Köhrle // Mol. Nutr. Food Res. - 2008. -, Vol.52. - I.11. - P. 1235 1246

14. Oberlis D. The biological role of macro- and micronutrients in humans and animals / D. Oberlis, B. Garland., A. Skalny // SPb. The science. - 2008. - 542 p.

15. Migues $P$. $V$. Dehydroepiandrosterone and its sulphate enhance memory retention in dayold chicks / P. V. Migues, A. N. B. Johnsto, S. P. R Rose // Neurosci. - 2002 -Vol. 109, I.2. - P. 243 -251 .

16. Commission Regulation (EC) No 1459/2005 of 8 Sept. 2005 amending the conditions for authorisation of a number of feed additives belonging to the group of trace elements. Official Journal of the European Union L233. - 2005 - P. 8-10

17. Herzig I. Utilisation of iodine from different sources in pigs / I. Herzig, B. Pisaikova, J. Kursa, P. Suchy // Arch Tierernahr. - 2000. - Vol. 53, N 2. - P. 179-189.

18. Antonyak H. L. Biokhimichna ta heokhimichna rol' yodu: monohrafiya. L. Antonyak, V. V. Vlizlo // LNU im. Ivana Franka, 2013. - 392 s. (in Ukrainian)

19. Artelt H. M. Selenium in Swine Nutrition / H. M. Artelt // RETORTE Ulrich Scharrer GmbH, Germany. -Vol. 10. - 2001. - P. 112-119.

20. Surai P. F. Is Organic selenium letter fjr animals than inorganic sources / P. F. Surai, J. E. Dvorska // Feed Mix. -2001. - Vol. 9. - P. 8-10.

21. Antyoksydantnyy status orhanizmu kurey $\mathrm{v}$ krytychni periody i rozvytku dlya dodatkovoho vykorystannya mineral'noyi dobavky do ratsioniv / YA. M. Sirko, B. YA. Kyryliv, V. O. Kystsiv, ta in. // Nauk.-tekhn. byul. In-tu biolohiyi tvaryn ta DNDKI vetpreparativ ta korm. dobavok. - 2014. - Vyp. 15, N 1. - S. 77-83. (in Ukrainian)

22. Lesyk YA. V. Rezystentnist' orhanizmu kroliv ta dynamiky masy tila krovi dlya umov reyestratsiyi spoluk khromu (III) ta sul'fatu natriyu / YA. V. Lesyk, R. S. Fedoruk, O. P. Dolaychuk // Biolohiya tvaryn. - 2014. - 16, № 3. - S. 76-84. (in Ukrainian) 
23. Tesarivs'ka U. I. Metabolichna ta toksychna diya riznykh doz «nanotsytrativ» I, Se, S v orhanizmi laboratornykh shchuriv / U. I. Tesarivs'ka, R. S. Fedoruk, V. H. Kaplunenko, ta in. // Visnyk Sums'koho natsional'noho ahrarnoho universytetu. - 2018. —№ 1 (42). - s. 220 - 224. (in Ukrainian)

24. European convention for the protection of vertebrate animals used for experim. and other scientific purposes. Coun. of Europe, Strasbourg. 1986. pp. 53.

25. Vlizlo $V$. $V$. Laboratorni metody doslidzhennya v biolohiyi, tvarynnytstvi ta veterynarniy medytsyni: dovidnyk / V. V. Vlizlo, R. S. Fedoruk, I. B. Ratych, ta in.; za red. V. V. Vlizla. - L'viv: SPOLOM, 2012. - 764 s. (in Ukrainian)

Рецензент - В. О. Величко, д. вет. н., ДНДКІ ветпрепаратів та кормових добавок 